\title{
(息)
}

Citation:

Bradley, Q (2012) A 'Performative' Social Movement: The Emergence of Collective Contentions within Collaborative Governance. Space and Polity, 16 (2). 215 - 232. ISSN 1356-2576 DOI: https://doi.org/10.1080/13562576.2012.721504

Link to Leeds Beckett Repository record:

https://eprints.leedsbeckett.ac.uk/id/eprint/541/

Document Version:

Article (Accepted Version)

The aim of the Leeds Beckett Repository is to provide open access to our research, as required by funder policies and permitted by publishers and copyright law.

The Leeds Beckett repository holds a wide range of publications, each of which has been checked for copyright and the relevant embargo period has been applied by the Research Services team.

We operate on a standard take-down policy. If you are the author or publisher of an output and you would like it removed from the repository, please contact us and we will investigate on a case-by-case basis.

Each thesis in the repository has been cleared where necessary by the author for third party copyright. If you would like a thesis to be removed from the repository or believe there is an issue with copyright, please contact us on openaccess@leedsbeckett.ac.uk and we will investigate on a case-by-case basis. 


\section{A "performative social movement": the emergence of collective contentions within collaborative governance}

To cite this article: Quintin Bradley (2012): A 'Performative' Social Movement: The Emergence of Collective Contentions within Collaborative Governance, Space and Polity, 16:2, 215-232

\section{Abstract}

The enmeshment of urban movements in networks of collaborative governance has been characterised as a process of co-option in which previously disruptive contentions are absorbed by regimes and reproduced in ways that do not threaten the stability of power relations. Applying a theoretical framework drawn from feminist philosopher Judith Butler this paper directs attention to the development of collective oppositional identities that remain embedded in conventional political processes. In a case study of the English tenants' movement it investigates the potential of regulatory discourses that draw on market theories of performative voice to offer the collectivising narratives and belief in change that can generate the emotional identification of a social movement. The paper originates the concept of the 'performative social movement' to denote the contentious claims that continue to emerge from urban movements that otherwise appear quiescent.

Key words

Urban movements; tenants' movement; collaborative governance; participation 
$\underline{\text { Introduction }}$

The restructuring of the state and public services propagated since the 1980 s by the rise of market theory, has presented urban movements with an ambivalent opportunity structure that rewards their absorption in networks of collaboration and partnership as service providers or convenient vehicles for the outsourcing of public services (Mayer 2000; Kavoulakos 2006). These strategies of collaborative governance have come to determine the terrain in which urban movements envisage the possibilities for enacting progressive policy (Swyngedouw 2005). Community organisations and campaigns, once committed to fundamental social change, have been reconstituted as resources for local economic regeneration, as models of initiative and enterprise, and as purveyors of the responsibility and self-help expected of subjects of government (Hamel, Lustiger-Thaler \& Mayer 2000; Fyfe 2005).

This process has been characterised traditionally as one of co-option, in which the contentions of urban movements are absorbed by regimes and reproduced in ways that do not threaten the stability of power relations (Pruijt 2003). Queer theorist and feminist philosopher Judith Butler has problematised the binary of militancy or quiescence implied in this tradition, arguing that urban movements exist in more complex and sometimes co-dependent interactions with established power relations. In her essays in Contingency, Hegemony, Universality co-authored with Laclau and Zizek, Butler (2000) illustrates how the exercise of contentious politics can enable regulatory intent and how movements appear to achieve recognition by replicating norms, and thereby reinforcing existing relations of power. Where co-option 
describes an external collective actor sucked into systems of governance, Butler appears to apply the concept of "domestication" to direct attention to the role of regulatory processes in giving rise to contentious claims. Importantly, for this paper, she maintains that movements can be called into existence by a discourse that seeks to deny them (Butler 2000: 157).

This contention appears to chime with recent studies of the restructuring of public services in the UK that have confirmed the ability of service users to resist, or subvert, the disciplinary intentions of governmental programmes that aim to transform their behaviour. Scholars have evidenced the ability of service users to contribute their own alternative imaginings to the construction of a new "public" (Clarke et al 2007; Barnes \& Prior 2009; Newman \& Clarke 2009; McKee 2010). They direct attention to the development of collective oppositional identities that remain embedded in conventional political processes, but may have the ability to widen the possible outcomes of policy intentions, and the potential for regulatory discourses to provide contentious movements with their strategies for change.

The aim of this paper is to investigate the extent to which collective contentious movements might be generated by individualizing state practices and regulatory schemes. It applies a theoretical framework drawn from the work of Judith Butler to examine collective contentions that emerge within conventional political systems and that may have the potential for transformative change. The paper begins by exploring some of the conceptual challenges posed to the study of urban movements by practices of decentred governance. It then advances a case study of the English tenants' movement as a domesticated urban movement and in extensive fieldwork 
evidences the construction of collective claims that appear generated by the regulated processes of user participation. The contribution this paper makes to the study of urban movements is to identify the components of regulatory discourse that enable contentious collective action and to provide an evaluative tool to assess the oppositional identities that emerge within collaborative governance.

\section{The domestication of urban movements}

Contemporary urban movements appear enmeshed in governance strategies that utilise technologies of collaboration and partnership to co-opt and moderate contentious politics. Studies have charted the domesticating effect of patronage from local government or institutional charities on previously disruptive movements (Mayer 2000; Kavoulakos 2006). They have observed the process of movement professionalisation and noted the loss of contention and the growing influence of "responsible" approaches in formerly contentious organisations (Zald \& Ash 1966; Piven \& Cloward 1977; Jenkins \& Eckert 1986). Some research, however, has questioned the degree to which urban movements are neutralised within these governance processes, and it is suggested that co-opted movements may continue to harbour contentious aims, and promote values that challenge dominant regulatory discourses (Cress 1997; Tarrow 1998; Pruijt 2003; Townsend, Porter \& Mawdsley 2004).

A number of theories have been put forward to understand the continuing contentions that emerge from these domesticated movements. Sidney Tarrow (1998) directed attention to cycles of protests, and the breadth of the repertoire of 
contentions used by movements. Alberto Melucci argued that social movements can exist in a latent stage and generate new meanings and codes that can lead to more visible and organised opposition (Melucci 1989). Verta Taylor and Nancy Whittier (1992) maintained that the feminist networks they studied remained "submerged" and in their collective latency were able to construct "a relatively stable point of reference from which to rebuild identities"(Melluci 1994: 127). Taylor's (1989: 761) concept of abeyance was applied to social movement organisations that appeared quiescent but that successfully provided continuity from one stage of mobilisation to another, and ensured the survival of ideas and beliefs. These studies of the continuity of contention within quiescent movements draw attention to the definitional vagaries of social movement studies, and the lack of specificity around what is meant by collective action, mobilisation or what a social movement that is not coopted should look like. Charles Tilly (1985: 736), the pioneer in this field, defined social movements without reference to the militancy of their mobilisation as "a series of demands or challenges to power holders in the name of a social category that lacks an established political position". More recently the concept of contentious politics (McAdam, Tarrow \& Tilley 2001) has been advanced to apply to any extraparliamentary influence exerted on governments. Helga Leitner and colleagues have put forward a more stringent definition that appears to focus on the types of claims made by movements:

"Forms of contestation in which individuals and groups organise and ally, with various degrees of formality, to push for social change that challenges hegemonic norms" (Leitner, Sheppard \& Sziarto 2007: 157). 
Alberto Melucci, writing in 1995, maintained that social movement theory had yet to answer the question of "how social actors form a collective and recognise themselves as part of it" (Melucci 1995: 42). His theory of collective identity addressed precisely that issue; it explained the construction and maintenance of organisational unity. Melucci pointed to three dimensions necessary to the construction of collective identity: the formation of cognitive frameworks concerning the goals, the means and the strategies of collective action, the development of group relationships through processes of communication, negotiation and decisionmaking, and the emotional commitment of participants to the collective and to each other (Melucci 1989: 35). While this framework appears to provide the litmus test of a social movement, collective identity has been interpreted more widely as in-group identification (Taylor \& Whittier 1995: 172) or simply "what movements do to construct a sense of 'we'” (Melucci 1989: 74). Carol Mueller (1994: 246) removed this elasticity from the concept when she argued that to evidence collective identity:

"Specific individuals must be identified who have formed emotional bonds from their interaction, negotiated a sense of group membership and made a plan for change (or a series of plans) however tentative, with goals, means, and a consideration of environmental constraints".

This statement provides a robust framework to evaluate urban movements that appear enclosed within authorised norms and state-endorsed relations of governance. It can also be applied to assess collective identities or oppositional contentions that may arise from, or be generated by regulatory practices that have individualising and disciplinary intent. In order to make these formations accessible 
to study as social movements, however, it is necessary to consider what is meant by "social change" when collective action is authorised by regulatory strategies, when organisations speak of compromise rather than contention, and their achievements are difficult to identify. The social change that may be proposed by these domesticated movements is for Judith Butler:

"Not a 'pure' opposition, a 'transcendence' of contemporary relations of power, but a difficult labour of forging a future from resources inevitably impure" (Butler 1993: 241).

Butler illustrates this conception of social change in a study of the rights-claims of gay and lesbian movements (Butler 2000). She argues that to demand human rights is to situate a movement within existing dominant conceptions of citizenship, in which the norm is presented as heterosexual, to the exclusion of gays and lesbians. In making a claim on human rights, gay and lesbian movements reiterate the norm of heterosexuality, and by doing so, make their claim intelligible within the existing boundaries of discourse. Yet their claim to rights presents homosexuality as potentially normative, and thereby challenges the limitations of the concept of human rights and the discourse of exclusion it maintains. The successful outcome of gay and lesbian campaigns for human rights will be their absorption into normative discourse; they will be "liberated into a new mode of subjection that the doctrine of citizenship has in store" (Butler 2000: 40). In Butler's thesis, the acts of resistance of social movements emerge in routine engagement with the exclusionary practices that provide them with intelligibility. The contentious politics of social movements are, then, projects of repeated erosion, what Butler (1993: 237) referred to as "working 
the weakness in the norm". They cannot achieve liberation; instead Butler talks of "critical subversion" and "radical resignification" (Butler 2004: 334). The process of achieving this ambiguous social change is described by Butler in her theory of performativity. She understands hegemony as a set of regulatory discourses that constitute social identity through exclusion. These regulatory norms are embodied in subjects and expressed through day-to-day social practice but they must be continuously renewed and performed in daily life through "a regularised and constrained repetition" and this reproduction may not produce an exact copy each time (Butler 1993: 95). Instead there is the potential to widen the range of what is considered normative. The way in which power relations are transformed, therefore, is through their daily reiteration (Butler 2000: 14). There is, however, no guarantee that iteration will bring change and Butler balances optimism with recognition of the constraints that constantly work to reinforce the social order (Butler 2000: 150). Her understanding that hegemony is inevitably unstable and is constantly threatened by the possibilities it has excluded foregrounds the potential for social change but provides no plan of action.

Judith Butler's theory has been criticised as too abstract, and for lacking specificity in how subversive practice is achieved (McNay 1999). As a tool of inquiry, however, Butler's thesis urges scholars to analyse the contentions put forward by urban movements that now appear part of the fabric of governance, and to chart the construction of collective contentions that many emerge from within regulatory practices. The next section examines a case study of the English tenants' movement, appearing as an exemplar of the domesticated social movement; now 
fragmented, individualised and enveloped in the co-optive practices of public participation.

\section{The domestication of an urban movement}

The network of local, regional and national tenants' organisations that is a feature of the English social housing sector is still described as a tenants' movement (Grayson 1997; National Tenants Voice Project Group 2008). However, the association of tenant collective action with an urban social movement (Castells 1978) has not survived the rise of public participation in social housing, or the fragmentation and marginalisation of the tenure. Tenant activists now appear enmeshed in the regulatory effects of participation policy or co-opted as surrogate managers in strategies of citizen governance (Sullivan 2001, McKee \& Cooper 2008) and it is unclear to what extent a tenants' movement can be evidenced in England and what, if anything, it aims to achieve.

Social housing is the term applied in England to describe homes provided by local authorities or registered landlords who are currently all non-profit making housing associations or co-operatives. A menu of participation opportunities has been instituted over forty years of policy promotion to 'ensure all social housing tenants have the confidence, skills and power to engage on housing and housing-related neighbourhood issues' (CLG 2009a: 22). The earliest initiatives of public participation in housing policy drew on tenant aspirations for democracy and usercontrol to institute the market dynamics of "choice" in welfare services, diversifying the management of public housing through tenant-run mutuals, reducing public 
ownership through transfer to housing associations, promoting "choice-based" lettings systems and projecting a self-image for tenants as active and responsible citizens rather than passive welfare recipients (Cochrane 2003; Flint 2004). In the decades after 1980 the social housing sector was shaped by a process of residualisation, first into a safety-net, then into an ambulance service for the most vulnerable households (Card 2001). Access to its shrinking stock was made conditional on extremes of housing need and the majority of new lettings went to those on the lowest incomes. Leached of its best properties and most affluent tenants through the privatisation measures of the Right to Buy, and the development of "mixed communities" with low cost home ownership or intermediate market renting, social housing became characterised as the carrier of deprivation, poverty and worklessness (Dwelly \& Cowans 2006) What were once mono-tenure housing estates, and portrayed by Stuart Lowe (1986) as potential social bases for tenant collective action, now appear to provide little ground for the generation of common cause.

The rise of public participation in social housing has been associated by commentators with the co-option and institutionalisation of the tenants' movement and the disappearance of autonomous contentious action (Goodlad 2001). While collective action remains a significant feature of the social housing sector - and membership of a tenants' association is the second most common form of "civic activism" in England (CLG 2009c) - this is mostly now channelled into the participation initiatives of housing organisations. The contemporary practice of participation advances a vision of a restructured public housing sector in which the market mechanisms of "choice" and "voice" (Hirschman 1970) sustain a strategy of 
centralised control and managerial delivery through quasi-privatised providers. In making decisions about goods and services and in seeking to wield influence over service providers, the tenant as welfare recipient is expected to learn from participation the rules of commodity exchange and to undertake an education in the responsibilities typically associated with property ownership, seen as the hallmark of the empowered citizen (Hart, Jones \& Bains 1997). In what has been called "the supermarket model" of public housing (Clapham \& Satsangi 1992: 66), autonomous tenants' organisations are caricatured as selfish interest groups disrupting the free exchange of goods and information (Barnes 1999) while market research recruits individual tenants as "data sources" for the business improvement of housing organisations (Beresford 1988: 39).

The contemporary tenants' movement is riven by the individualising effects of these practices, and characterised by its lack of unity. The Tenants \& Residents Organisation of England (TAROE), established in 1997, together with national organisations for tenant management and co-operative housing have only limited support compared to the tenant participation consultancy, TPAS, which has a national membership of 1,195 tenant organisations but is governed by a management board that includes landlords' representatives. Three regional tenants' federations and a further 37 sub-regional tenants federations are constituted, 14 of which describe themselves as Tenant Participation Networks or Involvement Groups and in some cases include landlord representatives on their committees, making clear their function as facilitators of participation with housing companies (IRIS Consulting 2010). At the last count there were more than 10,000 local tenants and residents associations on social housing estates (Aldbourne Associates 2001, Cole 
et al 2001), but these neighbourhood groups are often set up and sponsored by social housing organisations to fulfil their requirements for customer involvement. Still more local tenants' organisations exist as constituted or informally assembled forums convened and mediated by landlords, while individual tenants can serve on scrutiny panels, monitor their landlord as tenant inspectors, or become directors of social housing organisations. While tenant disruption continues in campaigns like Defend Council Housing, the line between a self-managed social movement and a landlord-led consultation process is now extremely unclear.

Despite the fragmentation of any organised movement, distinctive and combative shared beliefs can still be discerned among the tenants and leaseholders engaged in formal participation (Millward 2005, Simmons \& Birchall 2006). A research strategy to investigate those continuing contentions, and to evaluate them against Melucci's three-dimensional concept of collective identity, assembled a sample of 144 residents engaged in formal participation processes with social landlords. The research sample were drawn from the three per cent of tenants who take part in formal participation (CLG 2009b), and so sheds light on the collective identity constructions of a minority of the occupants of social housing, but the findings reflect upon the 38 per cent of social housing tenants who have less formal involvement with tenants' organisations (TSA 2009). The sample included tenants and residents associations and federations, tenants' panels and forums, individual tenant directors and tenant inspectors, tenant management organisations, regional and national tenants' organisations and tenant campaign groups. Data collection was carried out through focus groups followed by semi-structured interviews and took place from mid-2008 to mid-2010, a period of enormous and fundamental change in the social 
housing sector that culminated in the election of a Coalition Government and the imposition of a package of tenure reform and rent restructuring. In total 12 focus groups were held with 133 participants. One focus group was held with participants from neighbourhood tenants and resident associations, one with individuals involved on a range of tenant panels, two were held with committee members of boroughwide tenants' federations (one of which was closely involved with the campaign group Defend Council Housing), one with board members of a tenant management organisation, and two with regional tenants' federations. Five focus groups were held at the annual conference of TPAS and brought together members of customer panels, tenant directors of social housing companies, and board members of tenant management organisations and other tenant-led housing companies with tenants' association committee members, and tenants' federation representatives. These focus groups were held as part of the conference in 2008, 2009 and 2010 and were advertised as open events and the attendees were self-selected, but reflected an extremely wide range of those engaged in participatory practices.

Semi-structured interviews were carried out with 11 participants, including two paired interviews, lasting one hour on average. The interviews followed-up themes that had developed in the focus groups and enabled the researcher to revisit focus group participants who might not have spoken freely in the group setting or who might have been silenced by the pressure of mutual agreement. Interviewees were selected from each organisational level: one interview was held with the chair of the national tenants' organisation, two with committee members of regional federations, two with city federation members, two with neighbourhood association organisers, one with a tenants' panel member, and two with tenant directors. The sampling strategy was 
conceived to attain a broad geographical spread of organisations and, in addition to the focus groups held at the national TPAS conference, data collection was carried out in four cities across England. Tenants and leaseholders from housing associations, stock transfer organisations, arms-length management organisations and retained council housing authorities were sampled, along with a number of owner-occupiers active in residents' organisations, although for simplicity the sample are referred to as 'tenants' throughout. Overall the sample reflected the profile of social housing tenants engaged in participation; 55 per cent were women and around 14 per cent were from ethnic minority communities while the majority of the participants were over the age of 50 . The questions that guided the focus groups were phrased to encourage exploration of aims, grievances, mobilisation and deliberation on strategies. The questions for the interviewees focused on their individual motivation, and encouraged reflection on their personal achievements, as well as deliberation on some of the frames of meaning that had surfaced in the group setting. Accounts in both interviews and focus groups were evaluated throughout for their consistency, and the findings were reported back to three further groups of research participants to provide an additional opportunity for triangulation. Although more than 140 people were involved in this research, inevitably some were more vocal than others, and some participants appear often in the pages that follow, however, it should not be assumed that they were alone in articulating these views. The research findings reveal a significant convergence of reflective experience and opinion evidenced across all the focus group discussions and supported in each individual narrative. The contention that there continues to be a tenants' movement is very widely shared and the aims of this movement are expressed in combative terms, as the next section explores. 
$\underline{\text { Imagining a collective actor in public participation }}$

Participation works to shape the identities of public service users, to address them as consumers and as self-governing members of communities. As an essential step in the reform of welfare services along market principles, participation has become a ritualised production that forecloses on elements of the empowered citizenship it promises (Barnes et al 2003). Excluded articulations of democracy, equality, and collective empowerment now form the "constitutive outside" (Butler 1993) to "responsible participation" (Paddison, Doherty \& Goodlad 2008), and serve as a constant reminder of the possibilities that have been foreclosed to impose order. This explains, perhaps, why a discourse that seeks to constitute service users as individuals and to describe public services through market relations appears to conjure from this research sample an imaginary of collective representation and collective action.

Ted: I see tenants as a movement.

Karen: $\mathrm{Mm}, \mathrm{mm}$

Moderator: Yes? So why do you think that?

Ted: Well, well we, we want to change things, we want to benefit, that's what, what we're doing

Stephanie: If one person can't do it then

Ted: We want to have a united front if

Karen: Yeah

Ted: If you want to change things. 
This exchange among tenant directors and tenant association members at a conference in 2008 signals the contention commonly expressed across the research sample that, despite the individualising practices of participation and the fragmentation of the networks of tenants and residents, these are still collective actors. In the same focus group, Elizabeth, a tenants' association organiser, endows this imaginary collective with a historical mission:

Elizabeth: It seems to me that now, whereas it was like trying to bring, tenants trying to get their voice heard, it seems to me as though the, uh, we're now bringing the landlords into the $21^{\text {st }}$ century.

Moderator: So tenants are making the running?

Elizabeth: I think so

Moderator: They're kind of in charge?

Elizabeth: I wouldn't say we were exactly in charge but we're letting them know, we know our rights now and the, well, a lot of the landlords still don't really like it, but treat them gently and we'll bring them into the $21^{\text {st }}$ century.

The ability to conjure a collective imaginary and endow it with a mission of progressive change is enabled by the rights claims that remain implicit in the regulatory practices of public participation, and the restructuring of public services they underpin. In the discourse of participation, the political right to "voice" has been elided with the civil rights of the citizen to participate in the market. The expectation of service quality and the ability to exercise consumer influence have become enshrined as constitutional rights for the users of public services (Barron \& Scott 1992). This confinement of political rights within a market transaction enables claims 
to be made on notions of justice that have been marginalised but not fully excluded (Nicholls \& Beaumont 2004). Participation promises equality at the same time as it confirms the subjection of tenants as recipients of a welfare service. In resolving to fight for their rights, tenants reference the traditional role of citizens and articulate themselves in a history of rights-claiming movements. They have no entitlement to occupy the place of citizens "but nevertheless demand that the universal as such ought to be inclusive of them" (Butler 2000: 39). This claim to the rights of citizenship is articulated as a basic entitlement in the discourse of participation, evidenced by these members of a tenants' panel.

John: A tenant is a tenant when all's said and done. They pay their dues like everybody else

Kevin: But I think what it is, is we believe that all tenants deserve the same rights as anybody else.

In a focus group discussion, Nick, a housing association tenant, applies the civil rights of the landlord-tenant contract to reclaim the political rights of collective action. By accessing a vocabulary of rights, Nick is able to exit the market definition of housing entirely and construct the outline of a decommodified service: housing as home and community; housing as a social right.

But it's about, it's the struggle to try to win rights that go beyond that original deal, offer from the landlord which is on the landlord's terms, I mean what you're given. I mean the tenants' movement is a kind of self-parodying term, because it's about your home. Tenant is what the landlord calls you, ((laughs)) 
you know, that's their term for you, you know, you know. It's your home and it's giving, it's working with your neighbours to give yourself rights to stay in that home and to make sure that home becomes a community.

The claim to rights forces identification with a more contentious politics and conjures a history of tenant struggle. In a discussion at a conference in 2009, Carmen, a tenant director and chair of a tenants' organisation, enacts the imaginary of a movement engaged in a long campaign for rights:

I always say it's fighting for the rights of tenants, I don't mean physically in fisticuffs, but it's about fighting. A lot of young tenants come on board and they think this has always been here. It has been a fight and it has been a struggle to achieve what we have achieved.

This theme of legacy is developed by John, a national tenants' organiser, who maintains:

People have fought long and hard to raise the profile of tenants and to ensure they get a fair crack of the whip from landlords whatever persuasion. And it's about continuing the work done by previous members of our communities and honouring their achievements and developing on what bricks they put in place and growing the opportunities.

Tenants who have been hailed as individual citizen-consumers by the discourse of participation here establish continuity with an urban social movement that once 
organised rent strikes and public disruption. The invocation of a popular movement for tenants' rights is confirmed in the same focus group by Wendy, a tenant director:

Any movement's got to get to the top as they did in Chartism in the Victorian days [...] Because tenants' cries have to be recognised at governmental level in order that action can be taken.

The discourse of participation presents a collectivising narrative of shared interests that rekindles a sense of common cause among tenants and enables them to talk into existence an imaginary collective. This "movement" is depicted as a campaign for the collective provision of social housing. The sense of legacy and historical progress constructed around the rights claims inherent to participation enables tenants to depict social housing as a service that has been won through the collective action of its residents. In an interview at his tenants' federation, Bernard, the chair of the organisation, says:

If it wasn't for the tenants' movement I'm afraid we'd all be in terraced houses with the lavvy at the end of the road.

At a national tenants' conference Robert, a council tenant and member of his tenants' association, argues that social housing encourages social interaction and that it is essentially a co-operative tenure, in contrast to the individualism of the private market: 
Social housing, social as in interacting with other human beings, that's what social means. We are in a great position because we've got a quality of life which is far superior to people stuck in their private bloody little houses.

Among the research sample, support for social housing is accompanied by assertions that associate it with the values of co-operation and solidarity. This provides a critical narrative on the trajectory of public policy that has championed home ownership as the only acceptable tenure and has undermined the public services that once insured against risk. In the discussion below, tenants in a regional federation argue that the incursion of market forces into public housing has destroyed the communion of mono-tenure public housing estates.

Richard: Yeah but it's the housing now, on estates, such as there was, going back when everybody was a tenant, a council house tenant, now there is so much interplay

Theresa: Diversity

Richard: With homeowners, right, that is, they're not doing their input into the estate as what the tenants are through their organisations

Rebelling against the central tenets of housing policy that promote mixed neighbourhoods and private ownership, tenants argue that social housing develops the bonds of community. Jane, a delegate at a meeting of her regional tenants' federation maintains that social housing tenants are: 
In the main, quite good about looking after their neighbours, joining in with things and so on, considering the other children on, you know, people's children on the estate and all this sort of thing. So actually they're probably more socially conscious than a lot of people who live outside the council house environment.

Continuing the discussion at the meeting, Jane posits a causal link between privatisation and increased turnover on estates, arguing that the loss of social housing undermines feelings of community and social harmony:

Jane: The problem we have on a lot of our estates now is, because of the Right to Buy, and because the original Right to Buy people have sold, we now have quite fragmented, um, communities. I live on a very small estate, personally, but, um, you know, you see people walking across the yard and, you know, round [through the estate] Harry: [Don't know them] Jane: You don't know them because they change so, so rapidly. Now the residents, who lived there a long time, whether they're leaseholders or tenants, have a tradition of having organised things regularly on the estate.

What is being advanced in this discussion is a revisionist frame in which a golden age of popular social housing was destabilised by the forces of privatisation with subsequent loss of neighbourhood relations. The association of social housing with community and solidarity provides a frame of contention that celebrates collective provision and collective action in opposition to the direction of public housing policy 
and its pursuit of market-led services and individualised risk. The regulated discourse of participation has supplied a matrix of rights-claims that enables tenants to overcome its individualising intent and imagine themselves as collective actors. Regulatory discourse can initiate collective and contentious claims, and can also provide a strategy whereby such claims may appear to be advanced. This both affirms the likelihood of contention, and ensures its domesticity, as the next section shows.

\section{The performative social movement}

An imaginary of a tenants' movement appears to be generated, at least within this research sample, by the regulated practices of participation in housing. Evaluated against Melucci's (1989: 35) three-part definition, the collective identity that is constructed by the participants demonstrates an emotional commitment to the idea of a social movement, and awards it motivational values, but reveals no strategies for change, nor has any organisation-building been evidenced. The "movement" is manifested in the language of struggle and rights, but expressed in an idealised litany of common cause. At a 2008 TPAS convention Stephanie defined her sense of the movement as:

I think it's one big group, passionate group with a common goal to improve our homes, the way we are treated by the government and also the community we live in. 
Although she attributes three specific goals to the definition of movement, Stephanie's "passionate group" is an emotional identification that conveys the feeling of being present at a convention of like-minded people. At another TPAS focus group in 2009, Barbara cites the networking that occurs at the convention to indicate a sense of wider unity between tenants:

I always feel amazed when you go to a meeting, somewhere perhaps for the first time and you're meeting a new group of people how you can sit around that table and you can talk, and at the end of it you realise you're all there for the same reason and that strength I think it gives you, well it gives you more strength to carry on because you're not alone

Although this feeling of movement gives Barbara strength it does so intangibly; there is no joint response, no agreed strategy arising from these meetings. Barbara returns to her neighbourhood feeling resolved, secure in the knowledge that elsewhere people are also acting alone. In the place of organisation-building or strategic purpose, there is a feeling of distant communion (Bell \& Newby 1978). In a focus group at the TPAS conference in 2008, a discussion about tenants' organisations leads to the following exchange with the moderator:

Moderator: Do you feel you belong to a tenants' movement?

Graham: If you want to call us a movement we've got to have a national strategy.

Moderator: Do you have a national strategy?

Mary: We have a national wish to have a national strategy. 
Winston: It would make the landlords sit up if all the tenants and all the panels were all singing from the same hymn sheet.

The proposal that tenants might agree a joint strategy is received as a novel suggestion that is worthy of consideration. Later, Sonia follows up this point in the discussion:

We need a manifesto, a link between all the many organisations; a statement of intent.

While Sonia refers to "all the organisations", Winston's definition of a tenants' movement should be noted; he says "all the tenants and all the panels". The reference to panels is to customer panels: the sounding boards, focus groups, and service review groups that are initiated by landlords to enable tenant participation. The movement, for Winston, is not a network of autonomous tenants' organisations but an assemblage of individuals recruited by their landlords.

Discussions of recruitment and mobilisation by tenants in this research appear blighted by the lack of movement definition and are conveyed in the same emotionladen idealism in which the image of the tenants' movement is itself expressed. The following catalogue of shared interests is put together by a tenants' federation to provide a framework for mobilisation: 
Julia: No matter what kind of a tenant you are whether you're housing association or whether you, you live in a council house, or, or council property, eh, we all want the same things Harry: We have lighting issues

Terri: Yep

Julia: We want a decent home to live in

Terri: Yep

Harry: We have road issues, we have rubbish issues

Terri: Yep

Julia: So it doesn't matter what kind of property you live in, whether as you say being a house owner, or being a tenant, you just want somewhere decent to live and somewhere where you feel safe, and comfortable in your environment.

In this litany of common cause, the definition of a tenants' movement is extended to all residents irrespective of income, location or any other distinguishing marks. This credulous belief in common ground among tenants and residents is supplied by the dominant model of participation and its reassuring message that divisions of power and status are of no account to rational actors. The language of participation policy admits of no structural obstacles to recruitment or mobilisation. Participation is in the interests of all; and since landlords and tenants share a common interest in improving the housing business, taking part is the responsible thing to do (Riseborough 1998; Flint 2004). A tenants' movement expressed through the language of participation thus views mobilisation as the fulfilment of a moral duty and the achievement of responsible citizenship. Its goals are achievable within existing power relations. In the following extract from a focus group at a tenants' conference, 
Joy uses the language of struggle to make a claim for the universal rights of tenants. When the moderator draws attention to the words used in the claim, the response from the other participants is significant.

Joy: You have to keep on and on fighting for the rights of you and the people around you.

Moderator: Is that how you see it, fighting for=

Joy: $\quad$ Yep

Moderator: $=$ Rights?

Paul: $\quad \mathrm{Mmm}$

Karen: Not necessarily

Stephanie: No, I don't see it

Ted: No, not so much a fight

Karen: No we don't have to

Ted: Perhaps a matter of, ahh, I find it from our area a matter of discussion to come to the right [compromise]

Stephanie: [Compromise]

Bruce: Yeah compromise

Karen: Yeah that's the word I was looking for.

Conflict with elites has no place in these tenants' vocabulary. When asked what the strategy of a tenant's movement should be, another focus group gave the answer:

To be consulted and not directed. To be considered at all time to be part of the system automatically. 
Participation is presented to tenants as a non-zero sum process of bargaining in which both they and their housing providers can make gains (Richardson 1983; Bengtsson 1995). The mere introduction of a new set of people into decision-making processes, it is argued, carries a transformative force that has power to break down barriers and initiate change. In housing organisations participation has been adopted as a "voice" mechanism "like the market" (Hirschman \& Nelson 1976: 386) and conflated with market forces. Participation is perceived to have performative powers to enact the social relations it describes. It can effect "behaviour modification in providers" (Paul 1994: 3) and bring about improvements in efficiency and effectiveness (Hirschman 1970). In John Austin's (1976) examples, the performative can constitute the institution of marriage by declaring a couple "man and wife", or bestow identity through the phrase "I name this ship". Participation does not just describe a situation or an action; the power of "voice" makes change happen; as Judith Butler (1997: 146) says "the word becomes the deed". In this excerpt Stephanie, a tenant chair of her housing board, cites the performative in her description of the process of participation:

If you put your case over strongly enough, and reasoned enough and argued enough then nine times out of ten they will take a second look at it and say well, well we haven't thought of it that way and you can actually, you can do quite a lot with just your voice.

Like most tenants describing the process of participation, Stephanie conveys a direct causal relationship between speaking to decision-makers and influencing their 
decisions, indicating her expectation of the performative effect of "voice". By exercising voice within the accepted conventional procedures of participation, tenants reference an idealised market in which providers are sensitive to consumer demand and cite an automatic process of market readjustment. "Giving tenants a stronger voice", "ensuring tenants' voices are heard" are common expressions used by participants in this research to describe the aims and action of participation and express the normative expectation that voice will exert its corrective force and bring about change. The authorised discourse of participation provides a plan for change that absolves tenants in this sample from the need to develop the "goals, means, and a consideration of environmental constraints" (Mueller 1994: 246) that might constitute them as something more than an imaginary collective. Participation provides a substitute for movement mobilisation by articulating an illusion of inevitable progress.

Certainly a sense of patient optimism imbues much of the tenant sample, illustrated in this comment from Cheryl, the director of a tenant-led housing company, at a TPAS conference:

We're still in this, what the gentleman over there would call a class system, and my obs-, I've only been involved as a council tenant for about the last 12 or 13 years, and my understanding is that people like us, now being given a voice, coming to conferences like this, etc has only been a recent development historically and it's going to take a long, long time but hopefully one day it will come and things will be much better as how we're looked at as council or tenants of whatever organisations. 
In participation tenants recognise a political environment that presents them with opportunities to rehearse contentious identities. It is a realm of possibility, where universal claims to rights and democracy may be articulated from market processes and governmental strategies. There is inevitability to this process; participating in the practices that cement these dominant identities presents the immanent possibility of contesting them, as tenants in the same discussion suggest. It is just a matter of time:

Cheryl: It's just going to take a long time

Robert: It's a big wheel

This is the politics of possibility (Gibson-Graham 2006); the belief that reiteration does not have to mean repetition, and that one day it will mean change. As Jean, chair of a tenant management organisation, says:

It'll be a long hard fight but we will certainly get there in the end

The rituals of participation have provided tenants with a strategy to achieve potential change: belief in the performative power of voice to enact what it describes. Belief in performative voice obviates the need to construct a unified collective actor. Tenants, therefore, talk into existence a "performative social movement" as an emotional collective enacted by the power of voice to initiate the social relations it names. This is a discursive construction of claims-making that is enabled and constrained by regulatory process and state systems. It is a movement born in the reiterative 
strategies of power, rather than in the strategies of change; a movement, therefore, of possibilities not plans.

The regulatory discourses of collaborative governance that co-opt tenants' organisations, and direct their collective action to meet the aims of public service reform, also act to generate the identity talk of a contentious collective. The "performative" tenants' movement is an oppositional identity that is constituted by regulatory discourse, which is contingent on that discourse and constrained by it. A performative social movement denotes the "reiterative power of discourse to produce the phenomena that it regulates and constrains" (Butler 1993: 2). It confirms that regulatory practices may generate contentious challenges from within their own contradictions. The collective action it inspires is mobilised through systems of collaborative governance that present the alluring possibility of change and recruit it for regulatory effect. This performative social movement advances new claims in extending the contradictions inherent in normative discourses intended to produce responsible and entrepreneurial citizen-consumers. It evidences no plan for change beyond its compliance with a discourse of partnership and negotiation, but in its claims for social rights and its support for public housing provision, this collective contention presents the potential for "critical subversion" (Butler 2004: 334) of the process of public service reform.

\section{Conclusion}

The ambiguous political opportunities offered by collaborative governance appear to have domesticated urban movements and reconstituted them as service providers or 
quiescent partners in participation. While it is possible to theorise the continuance of movement contentions within a framework of domestication, and to study the latency or abeyance of social movement values and beliefs, this paper has argued for an appraisal of the effect of domesticating discourses on generating and sustaining new contentious claims. In particular it has drawn attention to the potential of regulatory discourses that promise to enhance service user influence, and that draw on market theories of performative voice, to offer both the collectivising narratives and the belief in change that can generate the emotional identification of a social movement. The paper has proposed the concept of the performative social movement to denote the contentious claims-making and oppositional identity talk generated by the normative discourses of public service reform.

In a case study the paper has evidenced the construction of a contentious collective among the fragmented tenant public addressed in policies of participation in social housing. Despite individualising intent, the regulatory practices of participation generate common cause among tenants and enable them to make discursive claims to be considered as a social movement. Tenants appear able to use the discourse of participation to launch contentions around public housing and social rights and to challenge the direction of public service reform. They construct an image of a social movement, enunciated through statements of value, demarcated by boundary markers and knitted together by emotional ties. Evaluated as a process of collective identity construction, these challenges do not achieve the definition of a social movement, with aims, organisations and plans for action. The tenants' movement invoked in participation is a performative construction rather than a coherent entity. It is clear, however, that individualizing state practices and regulatory schemes can 
provide the discourse through which challenging claims may be developed, and in the resilience of collective contentions it is possible to glimpse a renewal of political contest in the opportunities of collaborative governance.

\section{$\underline{\text { References }}$}

Aldbourne Associates (2001) A Study of Tenant Participation in Registered Social Landlords. London. The Housing Corporation.

Austin, J. L, (1976) How To Do Things With Words. Oxford. Oxford University Press

Barnes, M. (1999) Users as Citizens: Collective Action and the Local Governance of Welfare. Social Policy \& Administration. Vol. 33, No. 1: 73-90

Barnes, M. \& D. Prior (2009) Subversive Citizens: power, agency and resistance in public services. Bristol. Policy Press

Barnes, M., J. Newman, A. Knops \& H. Sullivan (2003) Constituting 'The Public' in Public Participation. Public Administration. Vol. 81, No.2: 379-399

Barron, A. \& C. Scott (1992) The Citizens' Charter Programme. Modern Law Review. Vol. 55: 526-546 
Bell, C. \& H. Newby (1978) Community, Communion, Class and Community Action. In: Herbert, D.T. \& R.J. Johnston (eds.) Social Areas in Cities. Chichester. John Wiley \& Sons

Bengtsson, B. (1995) Housing in Game-Theoretical Perspective. Housing Studies. Vol. 10, No. 2: 229-243

Beresford, P. (1988) Consumer Views: data collection or democracy? In: White, Ian, Mike Devenney, Reba Bhaduri, Jack Barnes, Peter Beresford, Adrianne Jones (eds.) Hearing the Voice of the Consumer. London. Policy Studies Institute

Butler, J. (1993) Bodies that Matter: on the discursive limits of sex. London. Routledge.

Butler, J. (1997) Excitable Speech: a politics of the performative. London. Routledge

Butler, J. (2000) Restaging the Universal: hegemony and the limits of formalism. In: Butler, Judith, Ernesto Laclau \& Slavoj Zizek, Contingency, Hegemony, Universality. London. Verso

Butler, J. (2004) Interview with Gary A. Olson and Lynn Worsham. In: Salih, Sara (ed.) The Judith Butler Reader. Oxford. Blackwell

CLG (Communities \& Local Government) (2009a) Directions to the Tenant Services Authority. London. Communities and Local Government Publications 
CLG (Communities \& Local Government) (2009b) Place Survey 2008, England:

Further results. Local Government Statistical Release. London. Communities and Local Government Publications

CLG (Communities \& Local Government) (2009c) 2007-08 Citizenship Survey Empowered Communities Topic Report. London. Communities and Local Government Publications

Card, P. (2001) Managing anti-social behaviour - inclusion or exclusion. In: Cowan, D. \& Marsh, A. Two Steps Forward. Bristol. The Policy Press.

Castells, M. (1978) City, Class and Power. Basingstoke. Macmillan

Clapham, D. \& M. Satsangi (1992) Performance Assessment and Accountability in British Housing Management. Policy \& Politics. Vol. 20, No.1: 63-74

Clarke, J., J. Newman, N. Smith, E. Vidler, and L. Westmarland (2007) Creating Citizen-Consumers: Changing Publics and Changing Public Services. London. Sage

Cochrane, A. (2003) The New Urban Policy: towards empowerment or incorporation? In: Imrie, Rob \& Mike Raco (eds.) Urban Renaissance? New Labour, community and urban policy. Bristol. Policy. 
Cole, I. P. Hickman, L. Millward, B. Reid, S. Whittle (2001) Tenant Participation in Transition: Issues and trends in the development of tenant participation in the local authority sector in England. London. Department of the Environment, Transport and the Regions.

Cress, D.I. (1997) Nonprofit Incorporation Among Movements of the Poor: pathways and consequences for homeless social movement organisations. The Sociological Quarterly. Vol. 38, No. 2: 343-360

Dwelly, T. \& J. Cowans (2006) Rethinking Social Housing. London, The Smith Institute

Flint, J. (2004) The Responsible Tenant and the Politics of Behaviour. Housing Studies, Vol.19, No.6: 893-909

Fyfe, N. (2005) Making Space for Neo-Communitariansism? The third sector, state and civil society in the UK. Antipode. Vol.37, No.3: 536-557

Gibson-Graham, J.K. (2006) A Postcapitalist Politics. London. University of Minnesota Press

Goodlad, R. (2001) Developments in tenant participation - accounting for growth. In: Cowan, D. \& Marsh, A. Two Steps Forward. Bristol, The Policy Press. 
Grayson, J. (1997) Campaigning tenants: a pre-history of tenant involvement to 1979. In: Cooper, C. \& Hawtin, M. (eds.) Housing, Community and Conflict: understanding resident involvement. Aldershot, Ashgate Publishing.

Hamel, P., H. Lustiger-Thaler \& M. Mayer (eds.) Urban Movements in a Globalising World. London. Routledge.

Hart, C., K. Jones \& M. Bains (1997) Do People Want Power? The social responsibilities of empowering communities. In: Hoggett, P. (ed.) Contested Communities: experiences, struggles, policies. Bristol, Policy Press.

Hirschman, A. (1970) Exit, Voice and Loyalty. Cambridge, Mass. Harvard University Press.

Hirschman, A. \& R. Nelson (1976) Discussion. The American Economic Review. Vol. 66, No. 2: 386-391

IRIS Consulting (2010) Regional and National Tenants' Organisations. London. Communities and Local Government.

Jenkins, J. Craig \& Craig Eckert (1986) Channelling Black Insurgency: Elite Patronage and Professional Social Movement Organisations in the Development of the Black Movement. American Sociological Review. Vol. 51, No.6: 812-829

Kavoulakos, K.-I. (2006) The emergence, development and limits of the alternative strategy of the urban movements in Germany. City. Vol.10, No. 3: 343-354 
Leitner, H., E. Sheppard \& K. Sziarto (2008) The spatialities of contentious politics. Transactions of the Institute of British Geographers. Vol.33, No.2: 157-172

Lowe, S. (1986) Urban Social Movements: the city after Castells. Basingstoke, Macmillan.

McAdam, D., S. Tarrow, C. Tilly (2001) Dynamics of Contention. Cambridge University Press.

McKee, K. (2010) Sceptical, Disorderly and Paradoxical Subjects: Problematizing the "Will to Empower" in Social Housing Governance. Housing, Theory \& Society. First published on: 21 May 2010 (iFirst)

McNay, L. (1999) Subject, Psyche and Agency: the work of Judith Butler. In: Bell, Vikki (ed.) Performativity and Belonging. London, Sage Publications.

Mayer, M. (2000) Urban Social Movements in an Era of Globalisation. In Hamel, Pierre, Henri Lustiger-Thaler \& Margit Mayer (eds.) Urban Movements in a Globalising World. London. Routledge

Melucci, A. (1989) Nomads of the Present: social movements and individual needs in contemporary society. London, Century Hutchinson

Melucci, A. (1995) The Process of Collective Identity. In: Johnston, Hank \& Bert Klandermans (eds.) Social Movements \& Culture. London, UCL Press. 
Millward, L. (2005) Just Because We Are Amateurs Doesn't Mean We Aren't Professional: the importance of expert activists in tenant participation. Public Administration, Vol. 83, No.3 735-751

Mueller, C. (1994) Conflict Networks and the Origins of Women's Liberation. In: Larafia, E.: Johnston, H.; Gusfield, J. (eds) New Social Movements: from ideology to identity. Philadelphia, Temple University Press

National Tenants Voice Project Group (2008) Citizens of Equal Worth. London. CLG

Newman, J. \& J. Clarke (2009) Publics, politics and power: Remaking the public in public services. London. Sage Publications.

Nicholls, W. \& J. Beaumont (2004) The Urbanisation of Justice Movements? Possibilities and constraints for the city as a space of contentious struggle. Space and Polity. Vol. 8, No. 2: 119-135

Paddison, R., I. Docherty, \& R. Goodlad (2008) 'Responsible Participation and Housing: Restoring Democratic Theory to the Scene', Housing Studies. Vol. 23, No.1: 129 - 147

Paul, S. (1994) Does Voice Matter? Policy Research Paper 1388. Washington. The World Bank Finance \& Private Sector Development Division.

Piven, F. F. \& R. Cloward (1977) Poor People's Movements. New York, Pantheon Books 
Pruijt, H. (2003) Is the Institutionalisation of Urban Movements Inevitable? A comparison of the opportunities for sustained squatting in New York City and Amsterdam. International Journal of Urban \& Regional Research. Vol. 27.1: 133157

Richardson, A. (1983) Participation. London, Routledge.

Riseborough, M. (1998) More Control and Choice for Users? In: Marsh, A. \& Mullins, D.(eds) Housing and Public Policy. Buckingham, Open University Press.

Simmons, R. \& J. Birchall (2006) Tenant Participation and Social Housing in the UK: applying a theoretical model. Housing Studies. Vol. 22, No.4 573-595

Sullivan, H. (2001) Maximising the Contribution of Neighbourhoods - The Role of Community Governance. Public Policy and Administration. Vol.16. No.2: 30-48

Swynegedouw, E. (2005) Governance Innovation and the Citizen: the Janus face of governance-beyond-the-state. Urban Studies. Vol. 42, No. 11: 1991-2006

TSA (Tenant Services Authority) (2009) Existing Tenants Survey 2008. London. Tenant Services Authority

Tarrow, S. (1998) Power in movement: social movements and contentious politics. Cambridge, Cambridge University Press 
Taylor, V. (1989) Social Movement Continuity: the Women's Movement in Abeyance. American Sociological Review. Vol. 54, No.5 761-775

Taylor, V. \& N. Whittier (1992) Collective Identity in Social Movement Communities. In: Morris, Aldon \& Carol McClurg Mueller (eds) Frontiers in Social Movement Theory. London, Yale University Press

Tilly, C. (1985) Models and Realities of Popular Collective Action. Social Research. Vol.52, No.4 717-747

Townsend, J., G. Porter \& E. Mawdsley (2004) Creating Spaces of Resistance: development NGOs and their clients in Ghana, India and Mexico. Antipode. Vol. 36, No.5: 871-889

Zald, M. \& R. Ash, (1966) Social Movement Organisations: growth, decay and change. Social Forces. Vol. 44, No.3 